\title{
Investigation on Recent Research of Mechanical Properties of Natural Fiber Reinforced Polymer (NFRP) Materials
}

\author{
PRABHU PAULRAJ ${ }^{1,2 *}$, KARTHIKEYAN BALAKRISHNAN ${ }^{3}$, \\ RAVI RAJA MALAR VANNAN RAJENDRAN ${ }^{4}$, BALAJI ALAGAPPAN ${ }^{5}$ \\ ${ }^{1}$ Department of Mechanical Engineering, Sriram Engineering College, Chennai, Tamilnadu, India, 602024 \\ ${ }^{2}$ Research Scholar, Department of Mechanical Engineering, Faculty of Engineering and Technology, Annamalai University, \\ Annamalai Nagar, Tamilnadu, India, 608002 \\ ${ }^{3}$ Department of Mechanical Engineering, Faculty of Engineering and Technology, Annamalai University, Annamalai Nagar, \\ Tamilnadu, India, 608002 \\ ${ }^{4}$ Department of Mechanical Engineering, Saveetha Engineering College, Chennai, Tamilnadu, India, 602105 \\ ${ }^{5}$ Department of Mechanical Engineering, A.V.C. College of Engineering, Mayiladuthurai, TamilNadu, India, 609305
}

Abstract. Renewability, recyclability and biodegradable contents are similar to glass fibers in natural fiber reinforced polymer composites (NFRP) which have definite mechanical properties. The interface of polymer matrix and natural fibers results the composites to achieve superior properties of products. Researchers have extended their product designs and production techniques by using renewable materials such as jute fiber, cotton fiber, silk fiber, etc. which are enormous and used in the manufacture of durable industrial goods of high-end quality. This paper reviews the current developments and the brief findings needed in literature, concentrating on the mechanical properties and applications of NFRP.

Keywords: Natural fibers, Composites, polymer, mechanical properties

\section{Introduction}

Natural fibers are biologically degradable, renewable and recyclable materials that help to create and produce composite materials [1]. Last few years, the addition of natural fibers from renewable and nonrenewable sources in polymer materials has obtained good physical and chemical properties in composite materials [2]. The fibers attained from plants like sisal, pine-apple, screw-pine bamboo, jute, oil-palm, flax, etc., in preference to artificial fibers like glass fiber as reinforcement are utilized the current trend of fabrication of green composites materials. For the reason of manufacturing natural fibers, they help to produce natural eco friendly environment system to obtain the improved corrosion and surface related tribology properties [3]. For special structural and non-structural applications, plantbased and animal-based fiber reinforced composites are still used every day. Natural fibers essentially contain of cellulose, hemicelluloses and lignin [4]. Natural fibers make loops, belts, wires, ties, mats, blankets, caps, baskets and sacks [5, 6]. Natural fibers have some disadvantages, such as greater water absorption by the thread, less interfacial interaction, instability at high temperatures, and unsuitability for matrix reinforcement in some fibers [7]. Surface modification in fibres plays a vital role in reinforced matrix bonding and result in decreasing the moisture content by chemical methods [8]. Natural fibers such as prosopis juliflora, abuliton indicum, and tapsi ( $\mathrm{T}$ ) are made in the form of straws by integrating fibers into neat epoxy resin. They give significantly improved tribology (wear) and mechanical properties of the composite material. Natural fiber composites with higher mechanical properties and environmental performance, it's necessary to impart hydrophobicity to the natural fibers by chemical modifications with appropriate coupling agents or by coating with suitable resins. In plants, the cells are joined together in different form of fiber lengths, coarse structures and stiffness of the cell walls [9].

Chemical treatments and physical treatments of natural fibers improve the bonding between natural fibers and matrix to form new composite materials [10]. Wax, lignin and oil containing parts of natural fibers are removed by physical treatment using chemicals. They increase the surface roughness of fibers, bonding of fibers with polymer matrix [11].

*email:prab_er@yahoo.co.in 
Setaria italic fiber reinforced in to lapox L-12 matrix resin composites and then treated with $\mathrm{NaOH}$ separates lignin and hemicelluloses from the fiber, which has improved the mechanical strength of the composite material. The interlayer binding between the prosopis

juliflora fiber and epoxy matrix resin composites is strengthened by alkali treatment resulting in the reduction of greasy nature over the fibers. By incorporating fillers, the tribological and mechanical properties are modified by using agro-waste filler in polymer composites as a reinforcing agent [12].

Now a days, many works done with hybrid natural fillers such as coir, rice husk, wheat raw, plant gum-rosin and pine bark in polymer materials are ideal for low cost enrichments of mechanical properties. India, Indonesia and China are the world's largest rice producers [13]. In this agricultural field, the major problem is the disposal of rice husk. For polymer composites, rice husk can be a very competent material as natural filler among many agricultural wastes [14]. There are so many natural fibers in recent years that help to boost mechanical properties. Sisal fiber is a lasting fiber obtained from the grasses of the agave family plant in the form of a long fiber bundle. Polyester resin is reinforced with natural sisal fiber and the hand-made mats are resulted in lower young modulus values than the machine-made mat [15]. The agro-waste fillers (Pine needle, rice husk, mustard cake and wheat straw) are added with grew optiva fiber and sisal fiber to help to enhance the sliding wear, hardness and impact energy properties of polymer composites [16]. By integrating steam detonation, alkaline curing, and micro grinding into the manufacturing of both white bamboo fibril micro and nano-sized ranges and their use as epoxy resin fillers, it has been shown to help enhance mechanical properties [17]. In this paper, there are numerous chemical treatments of reinforced composites of natural fibers for good mechanical properties that have been analyzed for further development.

\section{Materials and methods}

\subsection{Composition of natural fibers}

Natural fibers [20], as shown in Figure 1 consist of pectin, cellulose, waxy materials hemicelluloses and lignin. Cellulose is the principal component of natural fibers that gives the fibers strong mechanical properties. The remaining constituent of polymer which is hemicelluloses in primary wall of the fiber resistant to hydrolysis. A fragrant structured matter called lignin is a complex compound having a cross - linked phenolic type structure in nature which gives more stable. Pectin is represented having high molecular weight polysaccharides present in cell walls of plant. The natural fiber includes organic and inorganic matters that are effective for odor, decomposed resistance, colour and natural fibers' coarse nature. The composition of few natural fibers $[18,19]$ is mentioned in Table 1.

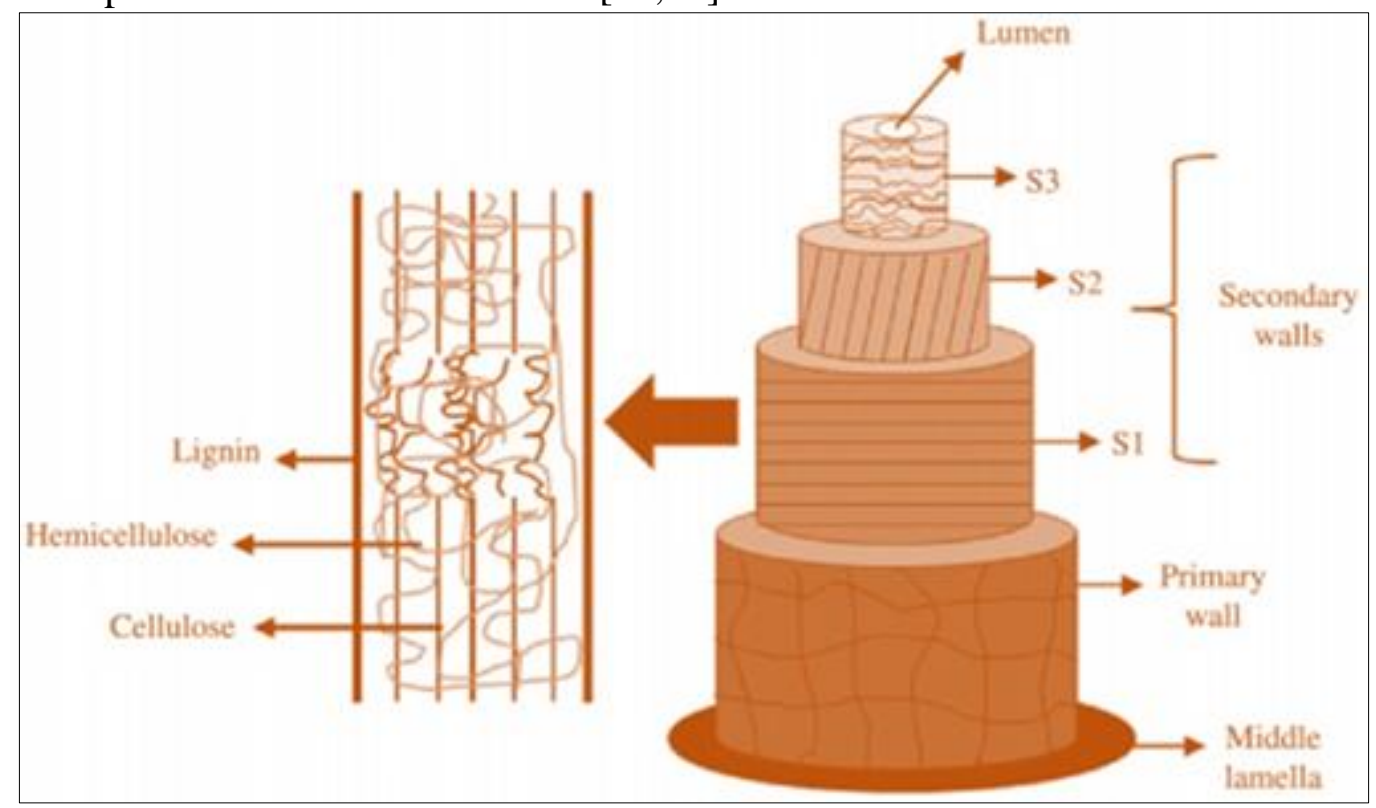

Figure 1. Schematic depiction of natural fibre cell [20] 
Table 1. Composition of Natural Fiber materials in research fields [18, 19]

\begin{tabular}{|c|c|c|c|c|c|}
\hline Fibers & $\begin{array}{c}\text { Lignin } \\
(\mathbf{w t} \%)\end{array}$ & $\begin{array}{c}\text { Pectin } \\
\mathbf{( w t \% )}\end{array}$ & $\begin{array}{c}\text { Cellulose } \\
(\mathbf{w t} \%)\end{array}$ & $\begin{array}{c}\text { Hemicellulose } \\
(\mathbf{w t} \%)\end{array}$ & Wax (wt\%) \\
\hline Jute & $11-15$ & $2.1-2.5$ & $60-72$ & $13.5-21$ & $1.5-1.9$ \\
\hline Cotton & $0.5-1.7$ & $1.1-6.9$ & $82-83$ & $2-6.4$ & $0.5-1.1$ \\
\hline Flax & $2.1-2.5$ & $2.1-2.5$ & $70-75$ & $18.5-21$ & $1.6-1.8$ \\
\hline Bamboo & $20-25$ & $0.5-0.7$ & $33-45$ & 30 & $0.3-0.5$ \\
\hline Hemp & $3.5-6$ & $0.8-1$ & $70-75$ & $17.5-22.5$ & $0.7-1$ \\
\hline Ramie & $0.5-0.7$ & $1.8-2$ & $68-77$ & $13-17$ & $0.2-0.5$ \\
\hline Sisal & $8-12$ & $10-12$ & $65-80$ & $10-15$ & $1-2$ \\
\hline banana & 5 & $8-10$ & $63-64$ & 19 & $04-0.8$ \\
\hline
\end{tabular}

\subsection{Natural fiber styles}

Natural fibers can be divided into two groups (1) Plant-related fibers and (2) Animal -related fibers. Plant-related fibers, including ramie, cotton, hemp, jute, kenaf, sisal, flax, coir, banana and bamboo, are typically blended with polymers to produce coupon of NFRP composites for domestic manufacturing $[5,6]$. The most important considerations for the manufacture of NFRP composites are strength and cost. Plant fibers derived from plants have long been used in construction to strengthen adobe and mud bricks, and are now being used in modern composites as substitute for synthetic reinforcing fibers made of glass or thermoplastic materials. These fibers are referred to as renewable sources and can be harvested from nature without impacting the environment and serve as a replacement of glass fiber for various engineering fields.

Animal fibers, on the other hand, are made up of protein structures that differ depending on the animal (or insect in the case of silk) from which they are obtained. However, they are typically scoured before use to extract surface fats, waxes, sweat, and soil, resulting in commercial types that are relatively cleaned during processing. Generally, Cocoon silk, fur, spider silk, chicken feather and hair are widely used as animal-related fibers, primarily for biomedical application as implant surgery. To prevent harmful to the human body, these fibers are required to be biodegradable or biocompatible [1].

\subsection{Manufacturing process}

The selection of manufacturing process for NFRP is based on their quantity of production, difficulty for making the final products, dimensional acceptance, cost and production time. Compared to artificial fibre composites, their manufacturing processes also influence the properties of NFRP composites. In manufacturing processes, parameters such as pressure and temperature are dominant to prevent natural fiber degradation and to ensure the consistency of NFRP composites.

Specific techniques to produce NFRP composites [21 - 23] are

- Hand and Spray lay,

- Filament winding,

- Injection and Compression moulding,

- Pre-impregnated NF/polymer film and

- Technique for vacuum infusion.

\subsubsection{Hand lay-up}

The hand and power controlled devices are used to cut the reinforcement materials to size during the manual lay-up process. These cut items are impregnated in a wet matrix and arranged over a mould that has been coated with a release agent and then usually a resin get-coat. To ensure uniform delivery and 
eliminate entrapped air, the impregnated reinforcement material in resin matrix is pressed by Hand rolled technique till the specified part thickness required [24].

\subsubsection{Filament winding}

Filament winding is a method of wrapping a tiny fiber string of threads of resin to incorporate in fiber along over the shaft of the required shape. After the shaft is removed, the hollow shape is formed. Pipe, tubing, pressure vessels, tanks, and similar items are all examples of filament winding applications. Hoop or helical winding is used in filament winding [25].

\subsubsection{Compression moulding technique}

Generally the most applicable method is Compression moulding technique stated below. Figure 2 illustrates the general process of manufacturing natural fibre composite materials using the technique of compression moulding.

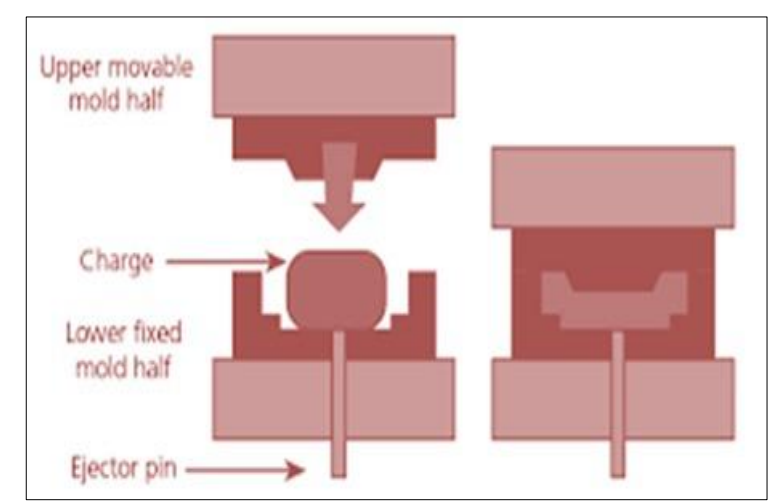

Figure 2. General Method of producing natural

fibre composite materials by Compression moulding technique [23]

Compression moulding is a traditional manufacturing method used in the manufacture of composites of the polymer matrix under varying temperatures and pressures. Due to the simplicity, this technique is widely used in the manufacture of composite materials. This cycle has benefits with respect to low turnover and speed of fibers. Nowadays compression moulding technique helps to fabricated natural fiber composites.

The compression and injection moulding processes are used in order to determine the better mixer system for fiber (sugarcane bagasse, benzylated bagasse and bagasse cellulose) and matrix (polypropylene). The samples (composites and polypropylene plates) were cut and sent to be analysed morphologically, microstructurally, and mechanically. The compression and injection moulding under vacuum process, which produced composites with a homogeneous distribution of fibers and no blisters, was the better-tested method for obtaining composites. The mechanical properties show that the composites have poor fiber-to-matrix adhesion; however, fiber incorporation improved the flexural modulus and material rigidity [26].

\section{Results and discussions}

\subsection{Natural fibers properties}

There are two components to produce composite materials, namely biodegradable natural fiber as shown in Table 2 (reinforcement) and metal, polymer and ceramics (matrix). Generally methods used are extrusion compounding, compression molding, injection molding and hand layup method [21-23] to fabricate polymer composite materials. As natural fiber is commonly increasing, their property is nonuniform. Even though the selection of natural fiber (reinforcement) composite is made based on price, environment friendly, and easily available in local markets. However, matrix selection depends on 
available manufacturing methods, material properties, environmental aspects and labor costs. It is concluded from Table 2, that young modulus for banana, bamboo and jute are higher than other natural fibers. The tensile strength is higher for banana, bamboo and jute fiber but density is more or less same. The mechanical properties are good for banana, bamboo and jute [27-32].

\subsubsection{Physical and mechanical properties of Natural fiber materials}

Matrix content of polymer is available in granule, board and acid form. Low density polyethylene (LDPE) and Polypropylenes (PP) are thermo plastic polymers that can be accessed as sheets and granules. Biodegradable polylactic acid (PLA) can be accessed as thin sheets and liquid. Polymer thermosetting such as polyester can be obtained as liquid and fiber. But epoxy is only available as liquid. Table 3 reveals that thermoplastic polymers have small young modulus relative to thermosetting materials. It provides strong tensile strength for thermosetting materials that are suitable for long fiber that requires long healing and complicated to recycling [33-37].

\subsubsection{Physical and mechanical properties of Polymer matrix materials}

Composites usually have different mechanical properties about the fraction of the fiber volume. From Table 4 it is considered the highest value and the lowest value of the fiber composites, but it lacks the volume fraction criterion of the fiber [38-96]. This paper gives the various authors with specific standard methods (ASTM) to evaluate the mechanical properties, but not underlined in this article. Due to cellulose and other materials, diameter in the portion of natural fiber is different in various regions. This also yields different fiber products which are varied due to composite properties. Usually bonding between the fiber and matrix interfaces guides the composite properties. Natural fibers are lightweight, eco-friendly and inexpensive resulting in lower flexural and impact properties of natural fiber polymer composites, due to partially or completely biodegradable polymer composite natural fibers. By modifying the fiber and matrix content physically and chemically, the properties of bio-based composite fiber material are improved.

Table 2. Physical and mechanical properties of various researchers in Natural fiber materials [27-32]

\begin{tabular}{|c|c|c|c|c|c|c|c|}
\hline Fibers & $\begin{array}{c}\text { Density } \\
(\mathbf{g m} / \mathbf{c c})\end{array}$ & $\begin{array}{c}\text { Tensile } \\
\text { strength } \\
(\mathbf{M P a})\end{array}$ & $\begin{array}{c}\text { Young's } \\
\text { modulus } \\
(\mathbf{G p a})\end{array}$ & $\begin{array}{c}\text { Flexural } \\
\text { strength } \\
(\mathbf{M P a})\end{array}$ & $\begin{array}{c}\text { Flexural } \\
\text { Modulus } \\
(\mathbf{G p a})\end{array}$ & $\begin{array}{c}\text { Impact } \\
\text { strength } \\
\left(\mathbf{K J} / \mathbf{m}^{2}\right)\end{array}$ & References \\
\hline Jute & $1.25-1.5$ & $300-780$ & $10-30$ & $18-37$ & $1.3-2$ & $3.2-7.5$ & 28.32 \\
\hline Cotton & $1.2-1.7$ & $300-600$ & $3-13$ & $20-72$ & $1-1.9$ & $1.9-3.5$ & 29.32 \\
\hline Flax & $1.5-1.55$ & $500-1500$ & $20-30$ & $50-60$ & $4-5$ & $2.5-8.3$ & 30.32 \\
\hline Bamboo & $1.31-1.35$ & $150-850$ & $20-36$ & $110-210$ & $13-14$ & $1-3$ & 30 \\
\hline Hemp & $1.47-1.6$ & $690-1100$ & $4-30$ & $63-65$ & $3.3-9$ & $2.6-2.7$ & 30.31 \\
\hline Ramie & $1.44-1.46$ & $400-700$ & $20-50$ & $60-100$ & ----- & $11-12.3$ & 30.32 \\
\hline Sisal & $1.34-1.50$ & $500-650$ & $3-22$ & $80-90$ & $1.1-3$ & $8-14.82$ & 32 \\
\hline banana & $1.30-1.40$ & $300-700$ & $30-35$ & $32-50$ & $2-5$ & $1.2-2.25$ & 27 \\
\hline
\end{tabular}

Table 3. Physical and mechanical properties range of various researchers in Polymer matrix materials [33-37]

\begin{tabular}{|c|c|c|c|c|c|c|c|c|}
\hline Material & Matrix & $\begin{array}{l}\text { Density } \\
\text { (gm/cc) }\end{array}$ & $\begin{array}{c}\text { Tensile } \\
\text { strength } \\
\text { (MPa) }\end{array}$ & $\begin{array}{c}\text { Young's } \\
\text { modulus } \\
\text { (Gpa) }\end{array}$ & $\begin{array}{c}\text { Flexural } \\
\text { strength } \\
(\mathbf{M P a})\end{array}$ & $\begin{array}{c}\text { Flexural } \\
\text { modulus } \\
(\mathbf{G P a})\end{array}$ & $\begin{array}{c}\text { Impact } \\
\text { strength } \\
(\text { Joules/m²) }\end{array}$ & References \\
\hline \multirow{3}{*}{ Thermoplastic } & PP & $0.88-0.93$ & $30-35$ & $0.8-0.9$ & $30-40$ & 1.0 & $20-60$ & 33 \\
\hline & PLA & $0.90-1.25$ & $25-66$ & $2.2-2.4$ & $45-110$ & $0.3-4$ & $26.8-72$ & 34 \\
\hline & LDPE & $0.89-0.92$ & $25-30$ & $0.18-0.23$ & $15-19$ & $0.1-0.3$ & $2.52-25$ & 35 \\
\hline $\begin{array}{l}\text { Thermoplastic / } \\
\text { Thermosetting }\end{array}$ & Polyester & $1.20-1.50$ & $20-40$ & $3-4$ & $37-45$ & $3-3.5$ & $3.37-8.24$ & 36 \\
\hline Thermosetting & Epoxy & $1.10-1.40$ & $70-75$ & $5-7.5$ & $55-65$ & $2.40-5.6$ & $21-39$ & 37 \\
\hline
\end{tabular}


Table 4. Physical and mechanical Properties range of various researchers in Natural fiber reinforced polymer composite materials [38-96]

\begin{tabular}{|c|c|c|c|c|c|c|c|}
\hline \multicolumn{2}{|c|}{ Composites } & \multicolumn{2}{|c|}{ Strength } & \multicolumn{2}{|c|}{ Modulus } & \multirow{2}{*}{$\begin{array}{c}\text { Impact } \\
\text { strength } \\
(\text { Kilo } \\
\text { Joules/m²) }\end{array}$} & \multirow[b]{2}{*}{ References } \\
\hline $\begin{array}{c}\text { Natural } \\
\text { Fiber }\end{array}$ & Matrix & $\begin{array}{l}\text { Tensile } \\
\text { (MPa) }\end{array}$ & $\begin{array}{c}\text { Flexural } \\
\text { (MPa) }\end{array}$ & $\begin{array}{c}\text { Young's } \\
\text { (GPa) }\end{array}$ & $\begin{array}{c}\text { Flexural } \\
\text { (GPa) }\end{array}$ & & \\
\hline Jute & \multirow{8}{*}{$\mathbf{P P}$} & $14-52$ & $30-80$ & $3-7.2$ & $2-5$ & $1.2-4.8$ & 38 \\
\hline Cotton & & $24-30$ & $42-91$ & $1.5-2.7$ & $1.9-2.2$ & $2.8-5.1$ & 39.40 \\
\hline Flax & & $33-82$ & $26-92$ & $2.4-6.9$ & $3.0-7.9$ & $0.95-1.1$ & 41 \\
\hline Bamboo & & $25-65$ & $35-81$ & $1-2.6$ & $1.2-4.6$ & 26.54 & 42.43 \\
\hline Hemp & & $25-35$ & $14-23$ & $0.6-2.2$ & $0.65-1.2$ & 24.5 & 44,45 \\
\hline Ramie & & $32-66$ & $42-68$ & $1.5-2.3$ & $1.4-2.6$ & $2.7-4.5$ & 46 \\
\hline Sisal & & $21-45$ & $30-68$ & $0.5-2.6$ & $2.8-5.5$ & $2-9$ & 47.48 \\
\hline Banana & & $28-40$ & $35-49$ & $1.9-2.4$ & $1.7-3.7$ & $10.8-17.8$ & 49.50 \\
\hline Jute & \multirow{8}{*}{ PLA } & $11-56$ & $35-100$ & $0.5-1.8$ & $2.3-6.2$ & $1-3.2$ & 51 \\
\hline Cotton & & $62-84$ & $105-143$ & $4.9-5.2$ & $6.2-8$ & $14-23$ & 52.53 \\
\hline Flax & & $147-310$ & $38-171$ & $5-29$ & $4.8-19$ & $5-26$ & 54.55 \\
\hline Bamboo & & $57-240$ & 104-200 & $2.5-3.1$ & $3-8.7$ & $7.7-9.5$ & 56.57 \\
\hline Hemp & & $21-75$ & $25-90$ & $3.5-12.7$ & $1.5-6.0$ & $7-7.6$ & 58.59 \\
\hline Ramie & & $59-63$ & $105-113$ & $4.3-4.7$ & $3.9-4.2$ & $5.0-6.4$ & 60 \\
\hline Sisal & & $36-60$ & $50-90$ & $0.5-2.5$ & $3.2-5$ & $3.2-26$ & 61 \\
\hline Banana & & $16-58$ & $26-102$ & $1.4-1.6$ & $4-5.2$ & $17-20.5$ & 62 \\
\hline Jute & \multirow{7}{*}{ LDPE } & $17-35$ & $20-31$ & $0.25-1.75$ & $0.6-1.5$ & - & 63.64 \\
\hline Cotton & & $10-20$ & $12-25$ & $0.2-1.1$ & $0.2-0.7$ & $81-90$ & 65 \\
\hline Flax & & $40-78$ & - & $0.005-0.38$ & - & $854 \mathrm{~J} / \mathrm{m}$ & 66 \\
\hline Bamboo & & $12-22$ & $10-30$ & $2.2-2.5$ & $3.5-3.9$ & $22-32$ & 67.68 \\
\hline Hemp & & $14-41$ & $11-47$ & $0.6-3$ & $0.5-4.1$ & $16-32$ & 69 \\
\hline Sisal & & $10-32$ & $15-45$ & $0.1-4.1$ & $2.5-4$ & $27-40$ & 70 \\
\hline Banana & & $9-15$ & $13-24$ & $0.3-1.2$ & $0.2-5.6$ & $7.5-27$ & 70.72 \\
\hline Jute & \multirow{8}{*}{ Polyester } & $64-83$ & $100-220$ & $1.5-5.7$ & 2.8-6.2 & $13-20$ & 73.74 \\
\hline Cotton & & $10-24$ & $36-62$ & $0.6-1.5$ & $3-4.6$ & $17-34$ & 75 \\
\hline Flax & & $82-280$ & $25-140$ & $2.2-6.5$ & - & - & 76 \\
\hline Bamboo & & $37-62$ & $75-98$ & $1.7-4$ & 4.8-6.7 & $15-18.1$ & 77 \\
\hline Hemp & & $20.1-53$ & $30-110$ & $3.7-6.2$ & $3.8-6.9$ & $7.2-13$ & 78.79 \\
\hline Ramie & & $18-30$ & $48-82$ & - & - & $3.2-4.8$ & 80 \\
\hline Sisal & & $21-60$ & $52-100$ & $0.4-2.2$ & $1.4-3$ & $15-25$ & 81.82 \\
\hline Banana & & $21-24$ & $24-47$ & $1.1-2.1$ & $0.9-2.4$ & $7-14.1$ & 83 \\
\hline Jute & \multirow{7}{*}{ Epoxy } & $45-50$ & $81-91$ & $0.2-0.3$ & $1.5-1.8$ & $69.5-88.5$ & 84 \\
\hline Cotton & & $26-58$ & - & $3-5.2$ & - & $26-42$ & 85.86 \\
\hline Flax & & $63-105$ & $78-130$ & $5-8$ & $4-9$ & $17-35$ & 87.88 \\
\hline Bamboo & & $85-100$ & $95-130$ & $4-6.8$ & $2-5$ & $20-70 \mathrm{~J} / \mathrm{m}$ & 89.90 \\
\hline Ramie & & $26-42$ & $62-90$ & 9.56 & - & $3-6.2$ & 91.92 \\
\hline Sisal & & $38-44$ & 51-110 & $6-10$ & $7-32$ & $1.3-1.5$ & 93.94 \\
\hline Banana & & 40-104 & $132-192$ & $1.6-2.4$ & $1.8-2$ & $2.5-2.8$ & 95.96 \\
\hline
\end{tabular}

\subsection{Natural fiber chemical treatments}

The enhancement of the properties of natural fibers is due to the process of chemical alteration by permanently altering the structure of polymer fiber cell walls as an implant on the fibers surface. This mechanism is identical to bulking in the cell wall of the fiber. The various chemicals used for natural fiber surface treatment are mentioned in Table 5 [97-111]. Chemical alteration provides fiber resistance to fungal decay, resistance to corrosion, reduced water absorption efficiency, reduced flammability and greater dimensional stability [20]. The interface adhesion between the fiber and the matrix can also be strengthened by chemical treatments. Therefore, in altering the properties of natural fibers, chemical treatments may be considered. Some compounds, such as alkaline (sodium hydroxide), acetic acid, peroxide, silane, isocyanates, potassium permanganate, acrylic acid, maleate coupling agents, etc., are known to facilitate adhesion by chemically coupling the adhesive to the content. Alkaline therapy can be considered the most economical option of all the methods; the only downside is the degradation in the strength of the fiber during the treatment. 
Table 5. Natural fibers materials treatment by Chemical modification in research fields [97 - 111]

\begin{tabular}{|c|c|c|c|c|}
\hline Name of treatment & $\begin{array}{l}\text { Chemical } \\
\text { Formula } \\
\end{array}$ & $\begin{array}{l}\text { Chemicals } \\
\text { Name }\end{array}$ & $\begin{array}{c}\text { Addition of } \\
\text { chemical }\end{array}$ & References \\
\hline $\begin{array}{c}\text { Succinic anhydride } \\
\text { Treatment }\end{array}$ & $\mathrm{C}_{4} \mathrm{H}_{4} \mathrm{O}_{3}$ & Oxolane-2,5-dione & $20 \mathrm{~g} / / \mathrm{L}$ & 97 \\
\hline $\begin{array}{c}\text { Benzoylation } \\
\text { Treatment }\end{array}$ & $\mathrm{C}_{6} \mathrm{H}_{5} \mathrm{COCl}$ & Benzoyl Chloride & - & 98 \\
\hline Silicone treatment & {$\left[\mathrm{R}_{2} \mathrm{SiO}\right]_{\mathrm{n}}$} & Polysiloxane & $15 \mathrm{~g} / \mathrm{L}$ & 98 \\
\hline $\begin{array}{l}\text { Diisocyanates } \\
\text { treatment }\end{array}$ & {$[\mathrm{R}-\mathrm{N}=\mathrm{C}=\mathrm{O}]_{2}$} & $\begin{array}{c}\text { Phenyl isocyanate toluene } \\
\text { diisocyanate, and hexamethylene } \\
\text { diisocyanate }\end{array}$ & $20 \mathrm{~g} / \mathrm{L}$ & 98 \\
\hline Acetylation treatment & $\mathrm{C}_{2} \mathrm{H}_{3} \mathrm{O}$ & Ethanoylation & $\begin{array}{l}10 \mathrm{wt} \% \text { in } \\
\text { methanol }\end{array}$ & 98 \\
\hline Silane treatment & $\mathrm{Si}-\mathrm{OH}$ & Saline/NaOH & $2 \%: 6 \%$ & 99 \\
\hline Cyclohexane & $\mathrm{C}_{6} \mathrm{H}_{12} / \mathrm{C}_{2} \mathrm{H}_{6} \mathrm{O}$ & Cyclohexane/Ethanol & $3 \%: 3 \%$ & 100 \\
\hline Alkalescent treatment & $\mathrm{NaOH}$ or $\mathrm{KOH}$ & $\begin{array}{c}\text { Caustic Soda (Potassium } \\
\text { hydroxide or Sodium hydroxide) }\end{array}$ & $5 \%, 7.5 \%, 10 \%$ & 101 \\
\hline $\begin{array}{c}\text { Perfluorocarbon } \\
\text { treatment }\end{array}$ & $\mathrm{C}_{\mathrm{x}} \mathrm{F}_{\mathrm{y}}$ & PFC & $30 \mathrm{~g} / \mathrm{L}$ & 102 \\
\hline Peroxide treatment & $\begin{array}{c}\mathrm{C}_{14} \mathrm{H}_{10} \mathrm{O}_{4} \text { or } \\
\mathrm{C}_{18} \mathrm{H}_{22} \mathrm{O}_{2} \\
\end{array}$ & $\begin{array}{l}\text { Benzoyl peroxide or Dicumyle } \\
\text { Peroxide }\end{array}$ & $60 \mathrm{~g} / \mathrm{L}$ & 103 \\
\hline $\begin{array}{l}\text { Permanganate of } \\
\text { Potash treatment }\end{array}$ & $\mathrm{KMnO}_{4}$ & Potassium manganate (VII) & $\begin{array}{l}(0.005-0.205) \% \\
\text { in acetone }\end{array}$ & 98,103 \\
\hline $\begin{array}{c}\text { Sulfuric acid } \\
\text { treatment }\end{array}$ & $\mathrm{H}_{2} \mathrm{O}_{4} \mathrm{~S}$ & Sulphuric acid & $2.0 \%(\mathrm{wt} / \mathrm{vol})$ & 104 \\
\hline Formic acid treatment & $\mathrm{HCOOH}$ & Methanoic acid & Solution of $1 \mathrm{~g} / \mathrm{L}$ & 105 \\
\hline Sodium Periodate & $\mathrm{NalO}_{4}$ & Sodium metaperiodate & $\begin{array}{l}\text { Solution of } \\
6.42 \mathrm{~g} / \mathrm{L}\end{array}$ & 106 \\
\hline $\begin{array}{l}\text { Maleic anhydride } \\
\text { treatment }\end{array}$ & $\mathrm{C}_{4} \mathrm{H}_{2} \mathrm{O}_{3}$ & Acid anhydride of maleic acid & $\begin{array}{c}15 \% \\
(\mathrm{Wt} / \mathrm{Vol})\end{array}$ & 107 \\
\hline Fatty acid of Stearic & $\mathrm{C}_{17} \mathrm{H}_{35} \mathrm{CO}_{2} \mathrm{H}$ & Octadecanoic acid & $\begin{array}{l}2 \% \text { solution in } \\
\text { ethanol }\end{array}$ & 108 \\
\hline Alkyl ketene dimer & $\mathrm{C}_{36} \mathrm{H}_{68} \mathrm{O}_{2}$ & Alkyl ketene dimer & $2 \%, 4 \%$ & 109 \\
\hline EDTA Edetic acid & $\mathrm{C}_{10} \mathrm{H}_{16} \mathrm{~N}_{2} \mathrm{O}_{8}$ & $\begin{array}{l}\text { Ethylene Diamine Tetra Acetic } \\
\text { acid }\end{array}$ & Solution of $5 \mathrm{~g} / \mathrm{L}$ & 110 \\
\hline $\begin{array}{c}\text { Carbamide (Urea) } \\
\text { Treatment }\end{array}$ & $\mathrm{CH}_{4} \mathrm{~N}_{2} \mathrm{O}$ & Carbamide & Solution of $2.17 \mathrm{~g} / \mathrm{L}$ & 111 \\
\hline
\end{tabular}

\subsubsection{Characterization of chemical treatment on the flexural properties and impact properties of NFRP}

The flexural specimens are systematized in compliance with the ASTM D790 specifications, and the tests are conducted using the universal testing machine (UTM). The three-point flexural test [112] is the most familiar flexural test and used in this experiment to evaluate the flexural strength and flexural modulus of the composite materials. The research set-up process involves the putting of the research specimen in UTM as a clearly supported beam and adding force to it, until it cracks and fractures.

Specimens for impact tests are prepared according to ASTM-A370/ ASTM6110/ ASTM D256 standards $[112,113]$. The specimen may be placed into the impact testing system during the testing process which allows the pendulum to crack or break the specimen. The impact value $\left(\mathrm{kJ} / \mathrm{m}^{2}\right)$ is determined using the impact method by dividing the energy of the fracture by the specimen's crosssectional area.

LDPE matrix banana fibers composites are manufactured and chemically treated by the two types (i) peroxide treatment and (ii) Potassium Permanganate treatment. Treatment with peroxide tends to enhance the $10 \%$ flexural properties of samples as compared with treatment with permanganate [114].

Polypropylene matrix / Jute fibers composite samples are made and treated chemically with formic acid, sodium and urea. The results show that the mechanical properties of the urea treated samples such 
as impact strength, flexural modulus and flexural strength are superior than those of the other treated and untreated samples [38].

Nylon matrix pine apple fibers composites are fabricated and chemically treated by alkali and silane. The results give that the improved flexural fiber properties for silane-treated pineapple fibers composites compared to untreated and alkali-treated pineapple fiber composites due to high aspect ratio. The absorption of pure nylon matrix's impact energy is greater than that of nylon / PALF composites [115].

Bagasse fibers are treated with alkali reinforced cardanol to form green composites. This finding shows that all mechanical properties such as flexural strength, flexural modulus and impact strength of composites of treated fibers are 15 percent of range higher than those of untreated composites of fibers [111].

Banana fibers / polyester composites are treated with silane and sodium hydroxide and blend together with the treatment of red mud elements (3-10 per cent). This finding shows that all mechanical properties such as flexural strength and impact strength of red mud elements composites of silane treated fibers are higher than those of sodium hydroxide treated fibers [116].

Banana fibers are treated with liquid solution of sodium hydroxide at varying concentrations to create composites of the banana/epoxy matrix. Flexural strength and impact strength of the treated fiber composites (0.5-1.5 per cent alkali concentration) are found to be greater than that of untreated fiber composites [117].

Sisal fiber / Epoxy composites are treated with alkali to form composites. Both the mechanical properties of impact strength and the flexural strength of composites of treated fibers are greater than that of untreated composites of fibers. The Figure 3 clearly shows that the crack is seen in sisal fibers due to load application acting in the perpendicular direction of the reinforcement of the Sisal fibers. This shows that alkali treatment with sodium hydroxide (8-12\%) is used to improve the adhesion properties of sisal epoxy fiber [118].
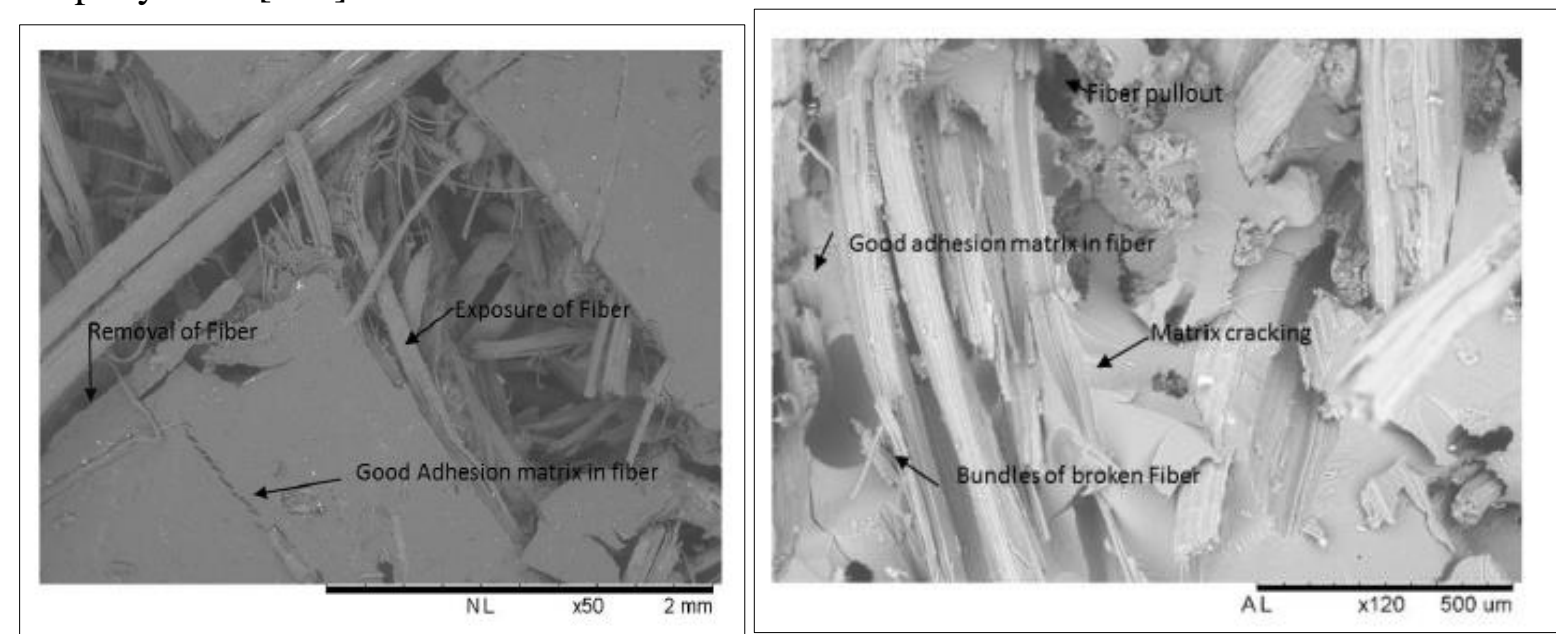

Figure 3. SEM of the treated sisal fiber composite material sample under

(a) Flexural test loading and (b) impact test loading [118]

Hydrothermal-treated bamboo particles / polyvinyl chloride composites are tested for the flexural strength of composites. The procedure helps to increase the flexural intensity up to $10 \%$ relative to that of untreated samples [119].

Composites of ramie / polylactic acid are treated as the compatibilizer with diisocyanates. Impact strength and flexural strength of treated fiber composites are greater than that of untreated fiber composites because of enhanced adhesion between polylactic acid and ramie [120].

Flax fibers / mimosa tannin resin are treated with four different therapies, including alkalescent, acetylation, silane and enzyme therapy. Such findings have shown that silane, alkalescent and acetylation therapies have more flexural properties than untreated fiber composites and enzyme therapy. Though 
treatment with $\mathrm{NaOH}$ has increased the energy effect to range of 4.75 to $5 \mathrm{~J}$ relative to untreated composites, impact properties of composites are less influenced [121].

Sisal fibers are processed and strengthened into epoxy resin by adding (1-2.5) percent solution of silane and alkaline. Reinforcing silanized sisal fibers through further enhancement of the mixing matrix reveal in flexural properties and impact properties are high compared to that of the pure epoxy mixing matrix [122].

Palm fibers are packed with calcium hydroxide and strengthened into cement mortar matrix with sodium hydroxide. This results in an assessment that the strengthening of the treated fibers gives composites greater flexural strength [123].

Alkalescent treated palmyra palm fibers and jute fibers are incorporated into polyester matrix resulting in an improvement of $20 \%$ respectively in the flexural properties of hybrid composites. Palmyra palm fiber's impact strength is greater than that of jute fiber and hybrid fiber [124].

A maleic anhydride binding agent is applied to two types of noil hemp fibers and scotched hemp fibers and strengthened into polypropylene matrix. For scotched hemp fiber composites, the flexural strength of composites is increased compared to that of noil hemp fiber composites by adding (1-4\%) coupling agent. Noil hemp fiber composites have a higher impact strength benefit than scotched hemp fiber composites with a $10 \%$ average difference of values [125].

Cylindrical Sansevieria fibers are treated with various stearic acid, potassium permanganate, benzoyl peroxide and alkali and strengthened into polyester matrix. The impact strength and flexural strength of composites treated with potassium permanganate are greater than that of other composites treated and untreated samples [126].

The author has examined the effect of chemical treatment (15\% solution of sulphuric acid followed by (0.5-2) \% alkali solution) on polypropylene composites amplified by sugarcane bagasse fibers. Impact strength and flexural properties of composites treated with fiber are stronger than those of untreated composites [127].

Coir and palm fibers are treated with benzene diazonium salt and form into a matrix of polypropylene. Coir fiber treated composites have obtained the maximum flexural strength and impact strength of all fiber loads compared to untreated coir and palm fiber composites [128].

The author has investigated the effects of alkali treatment on bamboo fiber / modified polyester composites that are unsaturated. The flexural properties of composites treated with bamboo fiber / modified polyester composites are increased related to untreated composites at room temperature [129].

The author has investigated the results of alkali treatment hybrid sisal / bamboo fibers bonded epoxy matrix composite. Flexural properties of hybrid composite treated are greater than those of untreated composites [130].

Chemically $1 \% \mathrm{H}_{2} \mathrm{SO}_{4}$ in single bath, assisted by therapy with $\mathrm{Na}_{3} \mathrm{PO}_{4}, \mathrm{Na}_{2} \mathrm{SiO}_{3}$, and $\mathrm{H}_{2} \mathrm{O}_{2}$ and further bath $\mathrm{NaOH}$ along with $\mathrm{Na}_{2} \mathrm{SiO}_{3}, \mathrm{Na}_{2} \mathrm{SO}_{3}, \mathrm{MgSO}_{4}$ treated jute fibers, the flexural properties are observed to be stronger than the raw jute composites [84].

The author has observed the effects of alkali treatment in bamboo fiber-reinforced polyester composite and incorporated Euphorbia coagulum as a binder for composite fabrication. Hybrid bamboo fiber / coagulum / polyester resin-based composite have increased the flexural strength and impact strength related to the remaining composites [131].

Textile composites (TFRP) are studied using separate chemical methods, including maleic anhydride binding agents, alkali - silane treatment, alkaline and silane. Maleic anhydride (MA) treated give better flexural properties, but alkali treated composites give high resistance to impact [132].

Silkworm fiber, filtek composite resin and silane coupling agent are used to fabricate Silk fiber reinforced composite material. The findings of the flexural strength check on the silk composites have revealed that the tension side value $(121.42 \pm 1.07 \mathrm{MPa})$ has showed the maximum flexural strength compared to neutral and compression [133]. 


\subsection{Applications of NFRP composites}

Generally green fibers are difficult to produce NFRP composites. Due to the following problems with climate conditions, harvested area, absorption of moisture, flammability, durability and interface are the key problems that resist the acceptance of NFRP composites in actual-life implementations [134139]. These factors have raised the degree of concerns regarding the properties of natural fibers in the manufacture of the product.

\subsubsection{Aerospace industries}

Due to temperature, strain, UV radiation and stress conditions, replacing artificial fibers on structural components is difficult in the aerospace engineering industry. The other effects have influenced aircraft structural components such as bird collisions, lightning strike, object strikes and water damage, causing catastrophic structural failure. Various therapies, strengthened in the matrix by carbon and nano particles to increase the electrical conductivity of NFRP composites are the rational approach today [134-136].

\subsubsection{Automotive manufacturing industries}

NFRP composites are ideal for body panels of vehicles as they substitute conventional composites of glass fibers and metal matrix composites and help to reduce vehicle costs and weight. Some applications include the roof covering, interior insulation, door panels, wheel box, molding rod / openings, trunk panel, backrest panel for seats, internal motor cover for trucks, seat / backrest, motor insulation, sun visor, bumper, glove box and instrument panel support $[137,138]$.

\subsubsection{Civil engineering industries}

Generally, if large quantities of fibers swarm together, the strength of concrete constructions is dramatically affected. Many development works are conducted in short natural fibers to increase the tensile strength in the cement process to reduce any crack formation. In this research on natural fiber, it has been stated that the chemical surface treatment with alkaline, sulfuric acid, silane, potash and other treatments on the surface of natural fibers that helps to reduce terrible conditions due to the severe environments such as hot temperatures and weather condition. Roofing and siding for housing have been produced in natural cellulose-cement composites. Besides that coating substances applied to structures help to prevent weather attacks [139].

\subsection{Disadvantages of NFRP composites}

Low impact strength (high proportion of fiber defects), difficulty storing raw material for long periods of time, UV resistance-not as good as plastics, fiber deterioration during processing, and fiber orientation and distribution are just a few of the drawbacks. The most difficult aspect of dealing with natural fiber reinforced polymer composite is the wide range of properties and characteristics available. Many factors affect the properties of a biocomposite, including environmental conditions (where the plant fibers are sourced), processing techniques, fiber grades, and any fiber alteration.

It is also known as polymer or biopolymer. The use of biopolymers as a matrix for biofiber reinforced composites has increased dramatically [140].

\section{Conclusions}

This review paper discuss about the natural fibers regarding composition, types, manufacturing process, properties chemical treatments and applications.

Alkali treatments used as main fiber therapies help to enhance flexural properties. Bonding between surfaces of composite materials has enhanced the flexural property due to chemical and coupling agent.

Combinations of treatments such as sulfuric acid + alkali, alkali + silane, alkali + diluted epoxy treatment have exhibited greater flexural properties than one treatment in particular.

Coupling agents such as maleic anhydride binders, euphorbia coagulum and zein have increased flexural strength effectively. 
Fatty acid of Stearic, formic acid, acetic acid and edetic acid have decreased the property of flexural strength of composites. Due to over addition of chemical leads to decay the fiber structure and their properties.

Physical therapies such as electron therapy, enzyme replacement therapy and hot water therapies have weakened the impact strength and flexural strength of composites.

Nowadays, several research works are carried out on different types of treatment combinations, matrix modification, fiber modification and binding agents on different fibers that help to improve flexural properties, impact properties and composite applications.

\section{References}

1.THYAVIHALLIGIRIJAPPA, YG., MAVINKERERANGAPPA, S., PARAMESWARANPILLAI, J., SIENGCHIN, S., Natural fibers as sustainable and renewable resource for development of eco-friendly composites: A comprehensive review, Front. Mater., 6, 2019,1-14.

https://doi.org/ 10.3389/fmats.2019.00226

2.SUMMERSCALES, J., DISSANAYAKE, NPJ., VIRK, AS., HALL, W., A review of bast fibres and their composites. Part 1 - fibres as reinforcements, Compos. Part. A. Appl. Sci. Manuf., 41 (10), 2010, 1329-1335, https://doi.org/10.1016/j.compositesa.2010.06.001

3.PRABHU, P., MOHAMED IQBAL, S., BALAJI, A., KARTHIKEYAN, B., Experimental investigation of mechanical and machining parameters of hybrid nanoclay glass fiber-reinforced polyester composites, Adv. Compos. Hybrid. Mater., 2, 2019, 93-101,

https://doi.org/10.1007/s42114-018-0065-y

4.BALAJI, A., KARTHIKEYAN, B., SWAMINATHAN, J., SUNDAR RAJ, C., Thermal behaviour of Cardanol resin reinforced $20 \mathrm{~mm}$ long untreated bagasse fiber composites, Int. J. Polym .Anal. Charact, 18(1),2018, pp.70-77, https://doi.org/10.1080/1023666X.2017.1387448

5.FARUK, O., BLEDZKI, A. K., FINK, HP., SAIN, M., Progress report on natural fiber reinforced composites, Macromol. Mater. Eng, 299 (1), 2014, 9-26, https://doi.org/10.1002/mame.201300008.

6.DITTENBER, DB., GANGARAO, HVS., Critical review of recent publications on use of natural composites in infrastructure, Compos. Part. A. Appl. Sci. Manuf, 43(8), 2012, 1419-1429.

https://doi.org/10.1016/j.compositesa.2011.11.019.

7.AZWA, ZN., YOUSIF, BF., MANALO, AC., KARUNASENA, W., A review on the degradability of polymeric composites based on natural fibres, Mater. Des, 47,2013, 424-442,

http://dx.doi.org/10.1016/j.matdes.2012.11.025

8.MADSEN, B., THYGESEN, A., LILHOLT, H., Plant fibre composites - porosity and stiffness, Compos. Sci. Technol, 69(7), 2009, 1057- 1069, https://doi.org/10.1016/j.compscitech.2009.01.016

9.ABDUL KHALIL, HPS., BHAT, A. H., IREANAYUSRA, A. F., Green composites from sustainable cellulose nanofibrils: A review, Carbo. Hyd. Polym. 87(2), 2012, 963-979,

http://dx.doi.org/10.1016/j.carbpol.2011.08.078

10.YAN, L., CHOUW, N., JAYARAMAN, K., Flax fibre and its composites - A review. Compos. Part B. Eng, 56, 2014, 296-317, https://doi.org/10.1016/j.compositesb.2013.08.014

11.JAWAID, M., ABDUL KHALIL, HPS., Cellulosic/synthetic fibre reinforced polymer hybrid composites: A review, Carbo. Hyd. Polym, 86(1), 1-18, 2011.

https://doi.org/10.1016/j.carbpol.2011.04.043

12.NANDO, GB., GUPTA, BR., Short fibre-thermoplastic elastomer composites, In: De SK, White JR (ed) Short fibre-polymer composites. Cambridge, England, Woodhead Publishing,1996, pp 84-115.

13.ZINI, E., SCANDOLA, M., Green composites: An overview, Polym. Compos, 32 (12), 2011, 19051915, https://doi.org/10.1002/pc. 21224.

14.REZA, A., AZMAN, H., KHALIQ, M., ZAINOHA, Z., (2015), Rice husk filled polymer composites, Int. J. Polym. Sci, 2015, 1- 32, https://doi.org/10.1155/2015/501471 
15.GRAIN, MM., SHAMITIBA, BK., PETER, M., CHIZYUKA, GC., Response of natural sisal reinforced polyester composites to three-point and four-point bending, Procedia. Manuf, 7, 2017, 327332, https://doi.org/10.1016/j.promfg.2016.12.080

16.SANDEEP, K., KRISHAN, KSM., BRIJESH, G., VINAY, KP., Synergy of rice-husk filler on physico-mechanical and tribological properties of hybrid Bauhinia-vahlii/sisal fiber reinforced epoxy composites, J. Mater. Res. Technol. 8(2),2019, 2070-2082. https://doi.org/10.1016/j.jmrt.2018.12.021

17.CUONG, MV., LE, HS, HYOUNG, JC., PHAM, TD, Effect of micro/nano white bamboo fibrils on physical characteristics of epoxy resin reinforced composites, Cellulose, 24(12), 2017, 5475-5486, https://doi.org/10.1007/s10570-017-1503-7

18.ANSELL, M P.,, MWAIKAMBO, LY., The structure of cotton and other plant fibres, In Eichhorn SJ , Hearle JWS , Jaffe M, Kikutani T (ed) Handbook of textile fibre structure, Cambridge, England , Wood head Publishing, 2, 2009, pp 62-94, https://doi.org/10.1533/9781845697310.1.62

19.LI, X., TABIL, L G., PANIGRAHI, S., Chemical treatments of natural fiber for use in natural fiberreinforced composites: A Review, J. Polym Environ, 15, 2007, 25-33.

https://doi.org/10.1007/s10924-006-0042-3

20.RAFAEL, S., SHIRANI, K., HARAGUCHI., EDVANI, C., MUNIZ., ADLEY, F., RUBIRA., Aplicaçoes de fibraslignocelulosicasnaquimica de polimeros E emcompositos, Quim. Nova, 32(3), 2009, 661-671. http://dx.doi.org/10.1590/S0100-40422009000300010

21.ISMAIL, NF., SULONG, A., MUHAMAD, N., THOLIBON, D., MDRADZI, M.K.F., WANLBRAHIM, W.A.S., Review of the compression moulding of natural fiber-reinforced thermoset composites: Material processing and characterisations, Pertanika. J. Trop. Agric, Sci 38, 2015, 533 547.

22.WU, MS., CENTEA, T., NUTT, SR., Compression molding of reused in-process waste - effects of material and process factors, Adv. Manuf. Polym. Compos. Sci, 4(1), 2018, 1-12.

https://doi.org/10.1080/20550340.2017.1411873

23.ZIN, MH., RAZZI, MF., OTHMAN, S., LIEW, K., ABDAN, K., MAZLAN, N., A review on the fabrication method of bio-sourced hybrid composites for aerospace and automotive application, IOP Conf. Ser: Mater. Sci. Eng, 152, 2016, 1-12. http://iopscience.iop.org/1757-899X/152/1/012041

24.THIRUCHITRAMBALAM, M., SHANMUGAM, D., Influence of pre-treatments on the mechanical properties of Palmyra palm leaf stalk fiber-polyester composites, J. Reinf. Plast. Compos, 31, 2012, 1400-1414, https://doi.org/10.1177/0731684412459248

25.SATHISHKUMAR, TP., NAVANEETHAKRISHNAN, P., SHANKAR, S., RAJASEKAR, R., Mechanical properties and water absorption of snake grass longitudinal fiber reinforced isophthalic polyester composites, J. Reinf. Plast. Compos, 32, 2013, 1211-1223,

https://doi.org/10.1177/0731684413485826

26.LUZ, SM., GONCALVES, AR., DEL'ARCO JR, AP., Mechanical behavior and microstructural analysis of sugarcane bagasse fibers reinforced polypropylene composites, Compos. Part A Appl. Sci. Manuf, 38(6), 2017 1455 - 1461, https://doi.org/10.1016/j.compositesa.2007.01.014

27.BALAJI, A., UDHAYASANKAR, R., KARTHIKEYAN, B., SWAMINATHAN, J., PURUSHOTHAMAN, R., Mechanical and thermal characterization of bagasse fiber/coconut shell particle hybrid biocomposites reinforced with cardanol resin, Results in Chemistry, 2020, p.100056. https://doi.org/10.1016/j.rechem.2020.100056.

28. ELSAYED, A., ELBADRY, MOHAMED, S., ALY, H., HIROYUKI, H., Mechanical properties of natural jute fabric/ jute mat fiber reinforced polymer matrix hybrid composites. Adv. Mech. Eng., 2012, $1-12$, https://doi.org/10.1155/2012/354547

29.SENDHIL KUMAR, S., ANBUMALAR, V., Selection and evaluation of natural fibers -A literature review. Int. J. Innov. Res. Sci. Eng. Technol, 2 (11), 2015, 929-939.

30.CELINO, A., FREOUR, S., JACQUEMIN, F., CASARI, P., The hygroscopic behavior of plant fibers: A review, Front. Chem, 1, 2014, 1 - 12, https://doi.org/10.3389/fchem.2013.00043 
31.SHAHZAD, A., A study in physical and mechanical properties of hemp fibres, Adv. Mater. Sci. Eng, 2013, 1-9, https://doi.org/10.1155/2013/325085

32.PICKERING, KL., EFENDY, MA., LE, TM., A review of recent developments in natural fibre composites and their mechanical performance, Compos. Part. A. Appl. Sci. Manuf, 83, 2016, 98-112, https://doi.org/10.1016/j.compositesa.2015.08.038

33.ABRAHAM, TN., GEORGE, KE., Studies on recyclable nylon-reinforced PP composites: Effect of fiber diameter, J. Thermoplast. Compos. Mater, 22(1), 2009, 5-20,

https://doi.org/10.1177/0892705708091603

34.MOKHENA, TC., SEFADI, JS., SADIKU, ER., JOHN, MJ., MOCHANE, MJ., MTIBE, A., Thermoplastic Processing of PLA/Cellulose Nanomaterials Composites, Polymers, 10(12), 2018, 1363 1392, https://doi.org/10.3390/polym10121363

35.RAMIN, S., DENIS, R., Rotomolding of Thermoplastic Elastomers Based on Low-Density Polyethylene and Recycled Natural Rubber, Appl. Sci, 9(24), 2019, 5430 -5450,

https://doi.org/10.3390/app9245430

36.HUSSAIN, M., KO, YH., CHOA, YH., Significant enhancement of mechanical and thermal properties of thermoplastic polyester elastomer by polymer blending and nanoinclusion. $\mathrm{J}$ Nanomater 2016, 1- 9, https://doi.org/10.1155/2016/8515103

37.LI, J., ZHANG, G., FAN, X., ZHOU, L., LI, J., SHI, X., ZHANG, H., Preparation and mechanical properties of thermosetting epoxy foams based on epoxy/ 2-ethyl-4-methylimidazol system with different curing agent contents, J. Cell. Plast, 53(6), 2017, 663-681,

https://doi.org/10.1177/0021955X17695095

38.UAWONGSUWAN, P., YANG, Y., HAMADA, H., Long jute fiber-reinforced polypropylene composite: Effects of jute fiber bundle and glass fiber hybridization, J. Appl. Polym. Sci, 132 (15), 2015, 1-13, https://doi.org/10.1002/app.41819

39.FARES, MC., GUSTAVO, DS., CARVALHO, AJF., Thermoformed Polypropylene Composite Reinforced with Cotton Fabric, Macromol. Symp, 383(1800068), 2019, 1-6,

https://doi.org/10.1002/masy.201800068

40.RUKMINI, K., RAMARAJ, B., SHETTY, SK., TARAIYA, A., BANDYOPADHYAY, SB., Development of Eco-Friendly Cotton Fabric Reinforced Polypropylene Composites: Mechanical, Thermal, and Morphological Properties, Adv. Polym. Tech, 32(1), 2013, 1-9

https://doi.org/10.1002/adv.21327

41.DOBAH, Y., ZAMPETAKIS, I., WARD, C., SCARPA, F., Thermoformability characterisation of Flax reinforced polypropylene composite material, Compos. Part. B. Eng, 184(1),2020, 1- 9, https://doi.org/10.1016/j.compositesb.2019.107727

42.WANG, C., YING, S., A Novel Strategy for the Preparation of Bamboo Fiber Reinforced Polypropylene Composites, Fiber. Polym, 15, 2014, 117-125,

https://doi.org/10.1007/s12221-014-0117-z

43.CHATTOPADHYAY, SK., KHANDAL, RK., UPPALURI, R., GHOSHAL, AK., Bamboo Fiber Reinforced Polypropylene Composites and Their Mechanical, Thermal, and Morphological Properties, J. Appl. Polym. Sci, 119, 2011, 1619-1626, https://doi.org/10.1002/app.32826

44.SUllinS, T., PILlAY, S., KOMUS, A., NING, H., Hemp fiber reinforced polypropylene composites: The effects of material treatments, Compos. Part. B. Eng, 114 ,2017, 15-22.

https://doi.org/10.1016/j.compositesb.2017.02.001

45.HAJNALKA, H., ILONA, R., RAJESH, DA., Development of HEMP Fiber Reinforced Polypropylene Composites, J. Thermoplast. Compos. Mater, 21, 2008,165-173.

https://doi.org/10.1177/0892705707083949

46.FENG, Y., HU, Y., ZHAO, G., YIN, J., JIANG, W., Preparation and Mechanical Properties of HighPerformance Short Ramie Fiber-Reinforced Polypropylene Composites, J. Appl. Polym. Sci, 122, 2011, 1564-1571, https://doi.org/10.1002/app.34281 
47.MUNDE, YS., INGLE, RB., SIVA, I., Effect of sisal fiber loading on mechanical, morphological and thermal properties of extruded polypropylene composites, Mater. Res. Express 6(8),2019, 1-16, https://doi.org/10.1088/2053-1591/ab1dd1

48.PRAJWAL, B., GIRIDHARAN, BV., VAMSHI, KK., MUZAMIL, HR., MOHAN, CB., Sisal fiber reinforced polypropylene bio-composites for inherent applications, Int. J. Recent .Technol. Eng, 8, 2019, 305-309, http://dx.doi.org/10.2139/ssrn.3510051

49.MAHESH, D., KOWSHIGHA, KR., RAJU, NV., PANKAJ, KA., Characterization of banana fiberreinforced polypropylene composites, J. Indian. Acad. Wood. Sci, 17, 2020, 1-8.

https://doi.org/10.1007/s13196-019-00244-X

50.HAYDAR, UZ., MUBARAK, AK., RUHUL, AK., Banana Fiber-Reinforced Polypropylene Composites: A Study of the Physico-Mechanical Properties, Fiber. Polym, 14(1), 2013, 121-126 https://doi.org/10.1007/s12221-013-0121-8

51.GUNTI, R., RATNA PRASAD, AV., GUPTA., AVSSKS, Preparation and Properties of Successive Alkali Treated Completely Biodegradable Short Jute Fiber-Reinforced PLA Composites, Polym. Compos, 37, 2016, 2161-70, https://doi.org/10.1002/pc.23395

52.CHEN, JC., LIN, JC., Manufacturing and properties of cotton and jute fabrics reinforced epoxy and PLA composites, Int. J. Mod. Phys. B, 32(19), 2018, 18400841- 18400845,

https://doi.org/ 10.1142/S0217979218400842

53.QIAN, J., YU, MM., GE, Z., XU, MJ., ZHANG, HH., YANG, GS., Preparation and Properties of Cotton Fiber/poly(lactic acid) Composites, Mater. Sci. Forum, 789, 2014, 100-105,

https://doi.org/10.4028/www.scientific.net/MSF.789.100

54.KHANLOU, HM., WOODFIELD, P., SUMMERSCALES, J., FRANCUCCI, G., KING, B., TALEBIAN, S., FOROUGHI, J., HALL, W., The mechanical properties of flax fibre reinforced poly(lactic acid) bio-composites exposed to wet, freezing and humid environments, J. Compos. Mater, 52(6), 2017, 835-850, https://doi.org/10.1177/0021998317714857

55.ALIMUZZAMAN, S., GONG, RH., AKONDA, M., Biodegradability of Nonwoven Flax Fiber Reinforced Polylactic Acid Biocomposites, Polym. Compos, 35, 2014, 2094-2102,

https://doi.org/10.1002/pc.22871

56.SHINJI, O., Flexural Properties of Long Bamboo Fiber/ PLA Composites, Open. J. Compos. Mater, 5, $2015,70-78$, http://dx.doi.org/10.4236/ojcm.2015.53010

57.ANGEL, PM ., ALFREDO, G., ANTONIO, FL., VERONICA, CV., SONIA DLRL., BambooPolylactic Acid (PLA) Composite Material for Structural Applications, Mater, 10(11), 2017, 1-22, https://doi.org/10.3390/ma10111286

58.ISLAM, MS., PICKERING, KL., FOREMAN, NJ., Influence of accelerated ageing on the physic mechanical properties of alkali - treated industrial hemp fibre reinforced poly(lactic acid) (PLA) composites, Polym. Degrad. Stabil, 95(1), 2010, 59-65,

https://doi.org/10.1016/j.polymdegradstab.2009.10.010

59.NINA, G., Improvement of the Mechanical Properties of Biodegradable Hemp Fiber Reinforced Poly (lactic acid) (PLA) Composites by the Admixture of Man-made Cellulose Fibers, J. Compos. Mater, 43(6), 2009, 689-701, https://doi.org/10.1177/0021998308100688

60.TAO, Y., NING, J., YAN, L., Study on short ramie fiber/poly (lactic acid) composites compatibilized by maleic anhydride, Compos. Part. A. Appl. Sci. Manuf, 64, 2014, 139-146,

https://doi.org/10.1016/j.compositesa.2014.05.008

61.ZHAOQIAN, L., XIAODONG, Z., CHONGHUA, P., Effect of Sisal Fiber Surface Treatment on Properties of Sisal Fiber Reinforced Polylactide Composites, Int. J. Polym. Sci, 2011, 1-7, https://doi.org/10.1155/2011/803428

62.UJENDRA, KK., MANISH, KL., INDERDEEP, S., PLA/banana fiber based sustainable biocomposites: A manufacturing perspective, Compos. Part. B. Eng, 180, 2020, 1-15,

https://doi.org/10.1016/j.compositesb.2019.107535 
63.KUTLAY, S., The Improvement of Mechanical Properties of Jute Fiber/LDPE Composites by Fiber Surface Treatment, J. Reinf. Plast. Comp, 29(13), 2010, 1921-1929, https://doi.org/10.1177/0731684409339078

64.RAHAMAN, MDN., HOSSAIN, MDS., RAZZAK, MD., UDDIN, MB., CHOWDHURY, AMS., KHAN, RA., Effect of dye and temperature on the physico - mechanical properties of jute/PP and jute / LLDPE based composites, Heliyon, 5(6), 2019, 1-9. https://doi.org/10.1016/j.heliyon.2019.e01753

65.BODUR, MS., BAKKAL, M., ENGLUND, K., Experimental study on the glass fiber/waste cotton fabric-reinforced hybrid composites: Mechanical and rheological investigations, J. Compos. Mater, 51(23), 2016, 3257-3268, doi:10.1177/0021998316685897

66.YAN, L., CHOUW, N., JAYARAMAN, K., Flax fibre and its composites - A review. Compos. B. Eng, 56, 2014, 296-317, doi:10.1016/j.compositesb.2013.08.014

67.ABHILASH, SS., SINGARAVELU, DL., Effect of Fiber Content on Mechanical and Morphological Properties of Bamboo Fiber-Reinforced Linear Low-Density Polyethylene Processed by Rotational Molding, Trans. Indian. Inst. Met, 73, 2020, 1549-1554, https://doi.org/10.1007/s12666-020-01922-y

68.ABDUL KHALIL, HPS., BHAT IUH., JAWAID, M., ZAIDON, A., HERMAWAN, D., HADI, YS., Bamboo fibre reinforced biocomposites: A review, Mater. Des, 42, 2012, 353-368,

https://doi.org/10.1016/j.matdes.2012.06.015

69.CHAUDHARY, SN., BORKAR, SP., MANTHA, SS., Sunnhemp fiber-reinforced waste polyethylene bag composites, J. Reinf. Plast. Compos, 29(15), 2010, 2241-2252,

https://doi.org/10.1177/0731684409345615

70.KURUVILLA, J., SABU, T., PAVITHRAN, C., Effect of ageing on the physical and mechanical properties of sisal-fiber-reinforced polyethylene composites, Compos. Sci. Technol, 53(1), 1995, 99 110, https://doi.org/10.1016/0266-3538(94)00074-3

71.BOLDUC, SS., JUNG, K., VENKATA, P., ASHOKCLINE, M., JAYASINGHE, R., BAILLIE, C., LESSARD, L., Banana fiber/low-density polyethylene recycled composites for third world eco-friendly construction applications - Waste for life project Sri Lanka, J. Reinf. Plast. Comp, 37(21), 2018, 13221331, https://doi.org/10.1177/0731684418791756

72.HAYDAR, UZ., MUBARAK, AK., RUHUL, AK., Physico- mechanical and degradation properties of banana fiber/ LDPE composites: Effect of acrylic monomer and starch, Compos. Interface, 18(8), 2011, 685-700, https://doi.org/10.1163/156855412X626261

73.JAMAL, H., HOSNE, AB., MOSLEM, UMD., MOHAMMAD, TI., ISLAM, MDM., Investigating the Physical Properties of Treated and Untreated Jute Fibre-Polyester, Composites. Asian J. Textile, 8 (1), 2018, 13-21, https://scialert.net/abstract/doi=ajt.2018.13.21

74.FARIDUL HASAN, KMF., MAZHARUL, I., MOHAMMAD, NM., SULTANA, MZ., MUEEID, MA., WU, JH., Influence of naturally originated jute on the fabrication \& mechanical properties of Jute/Polyester hybrid composite, Am. J. Polym. Sci. Eng, 4, 2016, 82-90.

75.ACHUKWU, EO., DAUDA, BM., ISHIAKU, US., Mechanical properties of plied cotton fabriccoated unsaturated polyester composites: Effects of alkali treatments, Int. J. Compos Mater, 5(4), 2015, 71-78, https://doi.org/10.5923/j.cmaterials.20150504.01

76.SAGAR, RC., PIYUSH, PG., Experimental investigations on flexural properties of longitudinally and transversely placed fiber reinforced polymeric composites, Int. J. Appl. Eng Res, 13(9), 2018, 7217 7223.

77.LIU, W., CHEN, T., WEN, X., QIU, R., ZHANG, X., Enhanced mechanical properties and water resistance of bamboo fiber-unsaturated polyester composites coupled by isocyanatoethyl methacrylate, Wood. Sci. Technol, 48, 2014, 1241-1255, https://doi.org/10.1007/s00226-014-0668-6

78.GILLES, S., NIHAT, SC., CALLUM, ASH., RTM Hemp Fibre - Reinforced Polyester Composites, Appl. Compos. Mater, 7, 2000, 341-349, https://doi.org/10.1023/A:1026538107200

79.QIU, R., REN, X., FIFIELD, LS., SIMMONS, KL., LI, K., Hemp fiber reinforced unsaturated polyester composites: Optimization of processing and improvement of interfacial adhesion, J. Appl. Polym. Sci, 121, 2011, 862-868, https://doi.org/10.1002/app.33674 
80.GUPTA, S., HAQ, MIU., MOHAN, S., ANAND, A., RAINA, A., DUTTA, V., VOHRA, K., KUMAR, R., Evaluation of mechanical properties of ramie/banana reinforced hybrid composites, J. Mech. Eng, 8(1), 2019, 95-104.

81.PRASAD, AR., RAO, KM., Mechanical properties of natural fibre reinforced polyester composites: Jowar, sisal and bamboo, Mater. Des, 32, 2011, 4658-4663,

https://doi.org/10.1016/j.matdes.2011.03.015

82.SILAS, MM., PAUL, MW., DAVID, NG., Mechanical properties of sisal/cattail hybrid-reinforced polyester composites, Adv. Mater. Sci. Eng, 2020, 1- 9, https://doi.org/10.1155/2020/6290480

83.MUTHUKANNAN, M., CHITHAMBAR GANESH, A., MUKILAN, K., Examination on Lightweight Banana Fibre (bunch) and Polyestercomposite for Industrial Applications, Int. J. J. Recent Technol. Eng, 8, 2019, 45-48.

84.WANG, H., MEMON, H., HASSAN, AME., MIAH, M., ALI, M., Effect of jute fiber modification on mechanical properties of jute fiber composite, Mater, 12, 2019, 1-12,

https://doi.org/10.3390/ma12081226

85.BACCOUCH, W., GHITH, A., ENIS, IY., SEZGIN, H., MILED, W., LEGRAND, X., FATEN, F., Enhancement of fiber-matrix interface of recycled cotton fibers reinforced epoxy composite for improved mechanical properties, Mater. Res. Express, 7 (1), 2020, 1-11,

https://doi.org/10.1088/2053 -1591/ ab6c04

86.MANJUNATH, R., SANJEEV, M., Behaviour of mechanical properties of natural fiber cotton and silk reinforced epoxy composite, Int. Res. J. Eng. Technol, 5(2), 2018, 1908 - 1914.

87.MUNOZ, E., MANRIQUE, JAG., Water absorption behaviour and its effect on the mechanical properties of flax fibre reinforced bioepoxy composites, Int. J. Polym. Sci. 2015, 1-10,

https://doi.org/10.1155/2015/390275

88.SATHISH, S., KUMARESAN, K., PRABHU, L., GOKULKUMAR, S., KARTHI, N., VIGNESHKUMAR, N., Experimental investigation of mechanical and morphological properties of flax fiber reinforced epoxy composites incorporating $\mathrm{SiC}_{\text {and }} \mathrm{Al}_{2} \mathrm{O}_{3}$, Mater. Today. Proc. 27(3), 2019, 22492253, https://doi.org/10.1016/j.matpr.2019.09.106

89.ZHANG, K., WANG, F., LIANG, W., WANG, Z., DUAN, Z., YANG, B., Thermal and Mechanical Properties of Bamboo Fiber Reinforced Epoxy Composites, Polym, 10(6), 2018,1-18,

https://doi.org/10.3390/polym10060608

90.GLORIA, GO., MARGEM, FM., RIBEIRO, CGD., MORAES, YMD., CRUZ, RBD., SILVA, FDA., MONTEIRO, SN., Charpy Impact Tests of Epoxy Composites Reinforced with Giant Bamboo Fibers, Mater. Res, 18(2), 2015, 178-184, https://doi.org/10.1590/1516-1439.360614

91.IRAWAN, AP., SOEMARDI, TP., WIDJAJALAKSMI, K., REKSOPRODJO, AHS., Tensile and flexural strength of ramie fiber reinforced epoxy composites for socket prosthesis application, Int. $J$. Mech. Mater. Eng, 6 (1), 2011, 46-50.

92.KUMAR, R., ANAND, A., Fabrication and mechanical characterization of Indian ramie reinforced polymer composites, Mater. Res. Express., 6(5), 2019, 1-16, https://doi.org/10.1088/2053-1591/aaff12 93.BALAJI, A., SIVARAMAKRISHNAN, K., KARTHIKEYAN, B., PURUSHOTHAMAN, R., SWAMINATHAN, J., KANNAN, S., UDHAYASANKAR, R., HAJA MADIEEN, A., Study on mechanical and morphological properties of sisal/banana/coir fiber-reinforced hybrid polymer composites, J. Braz. Soc. Mech. Sci. Eng, 41, 2019, 1-10, https://doi.org/10.1007/s40430-019-1881-X 94.PANDYA, Y., PATEL, N., PATEL, B., SUTHAR, N., Investigation of Tensile and Flexural Strength of Sisal Fiber Reinforced Epoxy Composite with Waste Tyre Rubber Particle as Filler, AIP. Conf. Proc, 2019, https://doi.org/10.1063/1.5130245

95.BALAJI, A., PURUSHOTHAMAN, R., UDHAYASANKAR, R., VIJAYARAJ, S., KARTHIKEYAN, B., Study on Mechanical, Thermal and Morphological Properties of Banana FiberReinforced Epoxy Composites, J. Bio. Tribo. Corros, 6(60), 2020, 1-10, https://doi.org/10.1007/s40735-020-00357-8 
96.ARTHANARIESWARAN, VP., KUMARAVEL, A., KATHIRSELVAM, M., Evaluation of mechanical properties of banana and sisal fiber reinforced epoxy composites: Influence of glass fiber hybridization, Mater. Des, 64, 2014, 194-202, https://doi.org/10.1016/j.matdes.2014.07.058

97.LESZCZYNSKA, A., RADZIK, P., SZEFER, E., MICUSIK, M., OMASTOVA, M., PIELICHOWSKI, K., Surface modification of cellulose nanocrystals with succinic anhydride, Polym, 11(5), 2019, 1-24, https://doi.org/10.3390/polym11050866

98.LI, X., TABIL, LG., PANIGRAHI, S., Chemical treatments of natural fiber for use in natural fiberreinforced composites: A review, J. Polym. Environ, 15, 2007, 25-33,

https://doi.org/10.1007/s10924-006-0042-3

99.MOHIT, S., GAURAV, D.,_Effect of fiber treatment on flexural properties of natural fiber reinforced composites: A review, Egypt. J. Pet, 27(4), 2018, 775-783,

https://doi.org/10.1016/j.ejpe.2017.11.005

100.WANG, J., WANG, A., Acetylated modification of kapok fiber and application for oil absorption, Fiber. Polym, 14, 2013, 1834-1840, https://doi.org/10.1007/s12221-013-1834-4

101.BALAJI, A., KARTHIKEYAN, B., SWAMINATHAN, J., Comparative mechanical, thermal, and morphological study of untreated and $\mathrm{NaOH}$-treated bagasse fiber-reinforced cardanol green composites, Adv. Compos. Hybrd. Mater, 2(1), 2019, 125-132,

https://doi.org/10.1007/s42114-019-00079-7

102.ERDOGAN, UH., SEKI, Y., AYDOGDU, G., KUTLU, B., AKŞIT, A., Effect of different surface treatments on the properties of jute, J. Nat. Fibers, 13(2), 2016, 158-171,

https://doi.org/10.1080/15440478.2014.1002149

103. JORDAN, W., CHESTER, P., Improving the Properties of Banana Fiber Reinforced Polymeric Composites by Treating the Fibers, Procedia. Eng, 200, 2017, 283-289,

https://doi.org/10.1016/j.proeng.2017.07.040

104. SOUZA, PS., RODRIGUES, EF., PRETA, JMC., GOULART, SAS., MULINARI, DR., Mechanical properties of Hdpe/textile fibers composites, Procedia. Eng, 10, 2011, 2040-2045, https://doi.org/10.1016/j.proeng.2011.04.338

105. SUN, Y., LIN, L., PANG, C., DENG, H., PENG, H., LI, J., HE, B., LIU, S., Hydrolysis of Cotton Fiber Cellulose in Formic Acid, Energ. Fuel, 21(4), 2007, 2386-2389, https://doi.org/10.1021/ef070134z 106. SULTANA, S., HUQUE, MM., HELALI, MM., Studies on the Physicomechanical Properties of Sodium Periodate Oxidized Jute Reinforced Polypropylene (PP) Composites, Polym. Plast. Technol. Eng, 46, 2007, 385-391, https://doi.org/10.1080/03602550601156045

107. MISHRA, S., NAIK, JB., Effect of Treatment of Maleic Anhydride on Mechanical Properties of Natural Fiber: Polystyrene Composites, Polym. Plast. Technol. Eng, 44, 2005, 663-675, https://doi.org/10.1081/PTE-200057814

108. BRODA, J., SLUSARCZYK, C., FABIA, J., DEMSAR, A., Formation and properties of polypropylene/stearic acid composite fibers, Text. Res. J, 86(1), 2016, 64-71,

https://doi.org/10.1177/0040517514566104

109. ZHANG, H., Effect of a novel coupling agent, alkyl ketene dimer, on the mechanical properties of wood - plastic composites, Mater.Des, 59, 2014, 130-134, https://doi.org/10.1016/j.matdes.2014.02.048 110. TERPAKOVA, E., KIDAlOVA, L., ETOKOVA, A., CIGASOVA, J., STEVUlOVA, N., Chemical modification of hemp shives and their characterization, Procedia. Eng, 42, 2012, 931 - 941, https://doi.org/10.1016/j.proeng.2012.07.486

111. BHANDARI, NL., DHUNGANA, BR., LACH, R., HENNING, S., ADHIKARI, R., Synthesis and characterization of urea-formaldehyde eco - friendly Composite based on Natural Fibers, J. Inst. Sci. Tech, 24(1), 2019,19-25, https://doi.org/10.3126/jist.v24i1.24623

112. ASHIK, KP., RAMESH,S., SHARMA, SUBASH P, Evaluation of tensile, flexural and Impact strength of natural and glass fiber reinforced hybrid composites, Renewable Bioresources, 5(1), 2017, 1-7,http://dx.doi.org/10.7243/2052-6237-5-1 
113. NAVARANJAN N, NEITZERT T (2017) Impact Strength of Natural Fibre Composites Measured by Different Test Methods: A Review. MATEC Web Conf 109, 2017, 1-7

https://doi.org/10.1051/matecconf/201710901003

114. JORDAN, W., CHESTER, P., Improving the Properties of Banana Fiber Reinforced Polymeric Composites by Treating the Fibers, Procedia. Eng, 200, 2017, 283-289,

https://doi.org/10.1016/j.proeng.2017.07.040

115. NOPPARUT, A., AMORNSAKCHAI, T., Influence of pineapple leaf fiber and it's surface treatment on molecular orientation in, and mechanical properties of injection molded nylon composites, Polym. Test, 52, 2016, 141-149, https://doi.org/10.1016/j.polymertesting.2016.04.012

116. ARUMUGA PRABU, V., UTHAYAKUMAR, M., MANIKANDAN, V., RAJINI, N., JEYARAJ, P., Influence of red mud on the mechanical, damping and chemical resistance properties of banana / polyester hybrid composites, Mater. Des, 64, 2014, 270-279.

https://doi.org/10.1016/j.matdes.2014.07.020

117. VENKATESHWARAN, N., ELAYAPERUMAL, A., ARUNSUNDARANAYAGAM, D., Fiber surface treatment and its effect on mechanical and visco - elastic behaviour of banana/epoxy composite. Mater. Des 47, 2013, 151-159, https://doi.org/10.1016/j.matdes.2012.12.001

118. BETELIE, AA., SINCLAIR, AN., KORTSCHOT, M., LI, Y., REDDA, DT., Mechanical properties of sisal epoxy composites as functions of fiber to epoxy ratio, AIMS. Mater. Sci, 6(6), 2019, 985-996, https://doi.org/10.3934/matersci.2019.6.985

119. QIAN, S., WANG, H., ZAREI, E., SHENG, K., Effect of hydrothermal pretreatment on the properties of moso bamboo particles reinforced polyvinyl chloride composites, Compos. Part B. Eng, 82, 2015, 23-29, https://doi.org/10.1016/j.compositesb.2015.08.007

120. YU, T., HU, C., CHEN, X., LI, Y., Effect of diisocyanates as compatibilizer on the properties of ramie / poly(lactic acid) (PLA) composites, Compos. Part A Appl. Sci. Manuf, 76, 2015, 20-27, https://doi.org/10.1016/j.compositesa.2015.05.010

121. ZHU, J., ZHU, H., IMMONEN, K., BRIGHTON, J., ABHYANKAR, H., Improving mechanical properties of novel flax/tannin composites through different chemical treatments, Ind. Crop. Prod, 67, 2015, 346-354, https://doi.org/10.1016/j.indcrop.2015.01.052

122. SRISUWAN, S., PRASOETSOPHA, N., SUPPAKARN, N., CHUMSAMRONG, P., The effects of alkalized and silanized woven sisal fibers on mechanical properties of natural rubber modified epoxy resin, Energy. Procedia, 56, 2014, 19-25, https://doi.org/10.1016/j.egypro.2014.07.127

123. OZERKAN, NG., AHSAN, B., MANSOUR, S., IYENGAR, SR., Mechanical performance and durability of treated palm fiber reinforced mortars, Int.J. Sustain. Built. Environ, 2(2), 2013, 131142, https://doi.org/10.1016/j.ijsbe.2014.04.002.

124. SHANMUGAM, D., THIRUCHITRAMBALAM, M., Static and dynamic mechanical properties of alkali treated unidirectional continuous Palmyra Palm Leaf Stalk Fiber / jute fiber reinforced hybrid polyester composites, Mater. Des, 50, 2013, 533-542. https://doi.org/10.1016/j.matdes.2013.03.048

125. YAN, ZL., WANG, H., LAU, KT., PATHER, S., ZHANG, JC., LIN, G., DING, Y., Reinforcement of polypropylene with hemp fibres, Compos. Part B. Eng, 46, 2013, 221-226,

https://doi.org/10.1016/j.compositesb.2012.09.027

126. SREENIVASANAN, VS., RAVINDRAN, D., MANIKANDAN, V., NARAYANASAMY, R., Influence of fibre treatments on mechanical properties of short Sansevieria cylindrica/polyester composites, Mater. Des, 37, 2012, 111-121. https://doi.org/10.1016/j.matdes.2012.01.004

127.CERQUEIRA, EF., BAPTISTA, CARP., MULINARI, DR., Mechanical behaviour of polypropylene reinforced sugarcane bagasse fibers composites, Procedia. Eng, 10, 2011, 2046-2051, https://doi.org/10.1016/j.proeng.2011.04.339

128. HAQUE, MM., HASAN, M., ISLAM, MS., ALI, ME., Physico-mechanical properties of chemically treated palm and coir fiber reinforced polypropylene composites, Bioresour. Technol, 100 (20), 2009, 4903-4906, https://doi.org/10.1016/j.biortech.2009.04.072 
129. SUGIMAN, S., SETYAWAN, PD., ANSHARI, B., Effects of alkali treatment of bamboo fibre under various conditions on the tensile and flexural properties of bamboo fibre/polystyrene-modified unsaturated polyester composites, J. Eng. Sci. Technol, 14(1), 2019, 26 - 46.

130. MOSISA, S., SIRHABIZU, B., Study and characterization of flexural and tensile properties of hybrid bamboo/sisal fiber reinforced epoxy composite, J. Mater. Sci. Eng, 8(2), 2019, 1-7.

131. KUMARI, S., KUMAR, R., RAI, B., KUMAR, G., Effect of fiber content on thermal and mechanical properties of euphorbia coagulum modified polyester and bamboo fiber composite, Mater. Res. Express, 66(12), 2019, 1-7, https://doi.org /10.1088/2053-1591/ab5d53

132. BODUR, MS., BAKKAL, M., SONMEZ, HE., The effects of different chemical treatment methods on the mechanical and thermal properties of textile fiber reinforced polymer composites, J. Compos. Mater, 50 (27), 2016, 3817-3830, https://doi.org/10.1177/0021998315626256

133. FAIZAH, A., MURDIYANTO, D., WIDYAWATI, YN., DEWI, NL., Effects of silkworm fiber position on flexural and compressive properties of silk fiber-reinforced composites, Dent .J, 51(2), 2018, 57-61, http://dx.doi.org/10.20473/j.djmkg.v51.i2

134. CHEUNG, HY., HO, MP., LAU, KT., CARDONA, F., HUI, D., Natural fibre-reinforced composites for bioengineering and environmental engineering applications, Compos. Part B. Eng, 40(7), 2009, 655-663, https://doi.org/10.1016/j.compositesb.2009.04.014

135. OLUSEGUN, DS., STEPHEN, A., TIMOTHY, AA., Assessing mechanical Properties of natural fiber reinforced composites for engineering applications, J. Miner. Mater. Char. Eng, 11, 2012, 780-784. 136. DICKER, MPM., DUCKWORTH, PF., BAKER, AB., FRANCOIS, G., HAZZARD, MK., WEAVER, PM., Green composites: A review of material attributes and complementary applications, Compos. Part A. Appl. Sci. Manuf. 56, 2014, 280-289,

https://doi.org/10.1016/j.compositesa.2013.10.014

137. HOLBERY, J., HOUSTON, D., Natural-fiber-reinforced polymer composites in automotive applications, J. Min. Met. Mater. Soc, 58(11), 2006, 80-86,

https://doi.org/10.1007/s11837-006-0234-2

138. KHAlFAllah, M., ABBES, B., ABBES, F., GUO, YQ., MARCEL, V., DUVAL, A., VANFLETEREN, F., ROUSSEAU. F., Innovative flax tapes reinforced Acrodurbio composites: a new alternative for automotive applications, Mater. Des, 64, 2014, 116-126

https://doi.org/10.1016/j.matdes.2014.07.029

139. MEHTA, G., MOHANTY, AK., THAYER, K., MISRA, M., DRZAL, LT., Novel biocomposites sheet molding compounds for low cost housing panel applications, J. Polym. Environ, 13(2), 2005, 16975, https://doi.org/10.1007/s10924-005-3211-x

140. FARUK, O., BLEDZKI, A. K., FINK, H.P., SAIN, M., (2012), Biocomposites reinforced with natural fibers: 2000-2010, Prog. Polym. Sci, 7(11), 2012, 1552-1596.

https://doi.org/10.1016/j.progpolymsci.2012.04.003

$\overline{\text { Manuscript received: } 2.04 .2021}$ 